\title{
TANTANGAN PESANTREN DALAM KOMERSIALISASI PENDIDIKAN DI TENGAH GLOBALISASI
}

\author{
Sholehuddin \\ Fakultas Ilmu Tarbiyah dan Keguruan UIN Syarif Hidayatullah Jakarta \\ Jalan Ir. Juanda Ciputat Jakarta \\ Email: sholeh_din@yahoo.co.id
}

\begin{abstract}
Abstrak:
Dewasa ini pendidikan termasuk pesantren tengah menghadapi tantangan globalisasi yang berakibat terjadinya komersialisasi pendidikan. Pada era ini tradisi umat manusia untuk mempertahankan eksistensi mereka melalui pendidikan termasuk di dalamnya pesantren mendapat tantangan serius, karena pendidikan ternyata bagi sebagian manusia digunakan untuk mengakumulasi kapital dan mengeruk keuntungan. Pendidikan dijadikan sebagai komoditi dan tidak semua masyarakat dapat mengaksesnya. Kenyataan inilah yang harus dihadapi dunia pesantren yang dituntut mampu memberikan layanan pendidikan bermutu dengan biaya murah. Pesantren adalah lembaga pendidikan yang tumbuh dan berkembang di tengah masyarakat dan menjadi motor penggerak pemberdayaan masyarakat itu sendiri, olehnya itu, ketika biaya pendidikan di pesantren mahal atau sulit dijangkau, maka pesantren akan terasing dari masyarakatnya.
\end{abstract}

\begin{abstract}
:
This adult education including schools facing the challenge of globalization, which results insilaisasi komer education. In this era of human tradition to maintain their existence through education included in its schools received a serious challenge, because education too real for some people used to accumulate tal capitalization and profits. Education used as a commodity and not all people can access it. It is this fact that must be faced by the schools were able to provide the required service quality education at a low cost. Pesantren there was the institution grow and develop in society and become a driving force of community itself, by him that, when the cost of education in schools is expensive or difficult to reach, then schools will alienate them from society.
\end{abstract}

Kata kunci:

Pesantren, globalisai, komersialisasi.

SECARA bahasa istilah pondok berasal dari bahasa Arab funduk, yang berarti tempat penginapan atau tempat bermalam. Pondok juga sering dimaknai dengan asrama yang juga berarti tempat tinggal. Dalam konteks ini, pondok merupakan tempat tinggal santri dalam menuntut ilmu. Di pondok tersebut, terjadi proses pembelajaran, terutama kitab-kitab kuning atau kitab-kitab Islam klasik. Di pondok juga terjadi proses komunikasi dan pembimbingan oleh kyai kepada santrinya, bahkan dalam waktu 24 jam. Dengan demikian dapat dilihat, urgensi pondok bagi suatu pesantren, pertama, banyaknya santri yang terus berdatangan dari berbagai daerah untuk menuntut ilmu kepada kyai. Kedua, pesantren-pesantren tersebut banyak terletak di desa-desa, di mana tidak tersedia perumahan atau penginapan untuk menampung 
banyaknya santri yang berdatangan dari luar daerah. Ketiga, ada sikap timbal balik antara kyai dan santri, di mana para santri menganggap kyai seolah-olah seperti orang tuanya sendiri. ${ }^{1}$

Secara bahasa pesantren berasal dari kata santri, dengan awalan "pe" dan akhiran "an" yang berarti tempat tinggal santri. Manfred Ziemek, secara etimologi pesantren berasal dari kata pesantrian yang berarti "tempat santri", belajar tentang berbagai bidang pengetahuan Islam. Istilah santri itu sendiri berasal dari bahasa Tamil yang berarti guru mengaji.

Tempat ini mengacu pada ciri utama pesantren, yakni lingkungan pendidikan secara menyeluruh dalam arti utuh. Pesantren identik dengan akademik militer atau cluster dalam arti bahwa mereka yang berpartisipasi dalam proses pengalaman belajar berada dalam keasyikan yang sempurna. Lembaga pesantren atau pondok terdiri atas seorang guru sebagai pemimpin yang pada umumnya sudah mendapatkan kesempatan pergi haji dan disebut kyai, serta sekelompok santri atau murid yang berjumlah ratusan bahkan ribuan. Aspek moral, akhlak, dan tasawuf adalah bagian terpenting yang diajarkan dalam pesantren. Selain itu, pada umumnya pesantrenpesantren yang berpengaruh menawarkan ajaran dan praktek tarekat bagi muridmurid yang tidak menetap di pondok atau yang disebut santri kalong. Biasanya kegiatan yang terakhir ini ditangani oleh guru sufi yang masyhur dan diikuti oleh ratusan atau ribuan yang cukup usia. ${ }^{2}$

Pondok pesantren yang berarti tempat tinggal para santri didefinisikan sebagai lembaga pendidikan dan pengajaran Islam non klasikal, di mana kyai mengajarkan ilmu agama kepada santri berdasarkan kitab yang ditulis dalam Bahasa Arab dan para santri tinggal di dalam pondok pesantren tersebut. ${ }^{3}$ Definisi ini menggambarkan unsur-unsur dasar suatu pesantren seperti disebutkan oleh Zamakhsyari Dhofier yaitu kyai, masjid, pondok (asrama), santri dan kitab kuning. ${ }^{4}$ Pesantren merupakan lembaga pendidikan Islam yang dikelola secara konvensional dan dilaksanakan dengan sistem asrama (pondok) dengan kyai sebagai tokoh sentral dan masjid sebagai pusat lembaga dan kegiatannya. Dunia pesantren tidak menutup diri terhadap perkembangan dunia luar.

Di samping pola tersebut, dalam perkembangan selanjutnya, sistem pendidikan pondok pesantren mengalami proses konvergensi, dalam hal ini setidaknya dapat diklasifikasikan menjadi lima tipe yaitu: Pertama, pesantren yang menyelenggarakan pendidikan formal dengan menerapkan kurikulum nasional, baik yang hanya memiliki sekolah keagamaan maupun yang memiliki sekolah keagamaan dan sekolah umum. Kedua, pesantren yang menyelenggarakan pendidikan keagamaan dalam bentuk madrasah dan mengajarkan ilmu-ilmu umum meski tidak menerapkan kurikulum nasional. Ketiga, pesantren yang hanya mengajarkan ilmu-ilmu agama dalam bentuk madrasah diniyah (diniyah ula, wustha, dan ulya). Keempat, pesantren yang hanya menjadi tempat pengajian (majelis taklim). Kelima, pesantren yang disediakan untuk asrama mahasiswa dan pelajar sekolah umum. ${ }^{5}$ 
Adapun mekanisme kerja pesantren mempunyai keunikan dibandingkan dengan sistem yang diterapkan dalam pendidikan pada umumnya, yaitu: ${ }^{6}$ pertama, mekanisme tradisional yang mempunyai kebebasan penuh dibandingkan dengan sekolah modern sehingga terjadi hubungan dua arah antara santri dan kyai. Kedua, kehidupan di pesantren menampakkan semangat demokrasi karena mereka praktis bekerjasama mengatasi problema non kurikuler mereka. Ketiga, para santri tidak mengidap penyakit simbolis, yaitu perolehan gelar ijazah karena sebagian besar pesantren tidak mengeluarkan ijazah, sedangkan santri dengan ketulusan hatinya masuk ke pesantren tanpa adanya ijazah tersebut, tujuan mereka untuk mencapai keridhaan Allah Swt. Keempat, sistem pondok pesantren mengutamakan kesederhanaan, idealisme, persaudaraan, penamaan rasa percaya diri, dan keberanian hidup. Kelima, alumni pondok pesantren tidak ingin menduduki jabatan pemerintahan, sehingga mereka hampir tidak dapat dikuasai oleh pemerintah.

Dalam proses perkembangannya, pondok pesantren dapat dikelompokkan menjadi dua, yaitu pesantren salaf atau tradisional dan pesantren khalaf atau modern. Tidak ada penjelasan yang komprehensif tentang kapan dan dari mana munculnya istilah salaf yang berarti tradisional dan khalaf berarti modern. Tidak ada literatur yang menjelaskan waktu dan sebab terjadinya pengotakan pesantren ke dalam "salaf dan khalaf". Munculnya pengotakan tersebut lebih dikarenakan faktor ortodoksi dan moderasi terhadap perubahan zaman. Dalam konteks ini istilah "salaf" bukanlah antonim dari "khalaf".

\section{GLOBALISASI}

Dewasa ini kita sering dihadapkan pada kata-kata "era globalisasi", bahkan dalam berbagai bidang kehidupan manusia, kata ini selalu hadir, termasuk dalam bidang pendidikan yang berarti bahwa pendidikan kita sedang dihadapkan dalam kenyataan kehidupan global. Globalisasi kini kian mendunia, gejala ini ditandai dengan pesatnya perkembangan teknologi komunikasi dan informasi, yang mengakibatkan terjadinya ledakan informasi di berbagai penjuru dunia. Perkembangan ini telah mendorong umat manusia untuk selalu bersiap diri dengan berbagai kemungkinan yang diakibatkan kuatnya gelombang informasi tersebut. Proses informatisasi yang cepat semakin membuat horison kehidupan di dunia ini semakin meluas dan sekaligus dunia ini semakin mengerut. Hal ini berarti berbagai permasalahan kehidupan manusia menjadi masalah global atau setidak-tidaknya tidak dapat dilepaskan dari pengaruh kejadian di belahan bumi yang lain, baik masalah politik, ekonomi maupun sosial. ${ }^{7}$

Disadari atau tidak, pesatnya perkembangan teknologi komunikasi dan informasi telah menyebabkan menipisnya perbedaan ruang dan waktu. Sebagaimana diketahui, bahwa suatu peristiwa yang terjadi di daratan Amerika dan Eropa dapat disaksikan di rumah masing-masing saat itu juga (saat peristiwa tersebut berlangsung). 
Kondisi seperti ini tidak bisa dihindarkan oleh siapapun dan di manapun termasuk oleh pesantren. Dalam hal ini "menghindar" bukanlah jawaban yang tepat dari kondisi ini. Oleh karena itu kalangan pesantren dituntut untuk mampu menghadapi kondisi ini dengan berbagai persiapan dan kemampuan yang dimiliki. Globalisasi menghadirkan sejumlah peluang dan tantangan yang sepenuhnya diserahkan kepada manusia untuk menyikapinya. Di sinilah kemampuan dan strategi pesantren sebagai lembaga pendidikan Islam dipertaruhkan, apakah ia mampu mengambil peluang tersebut untuk kebaikannya ataukah ia malah terjebak dan bahkan kalah dari tantangan yang dihadapi.

Dalam prosesnya, dinamika perkembangan zaman dengan berbagai konsekuensinya terus berjalan seiring dengan proses modernisasi yang menuntut pesantren untuk mau menerima perubahan dan perkembangan yang terjadi, namun demikian, masih terdapat pola baku sebagai hal esensial dunia pesantren yang dinilai relatif ajeg dan kontinu terkait sistem nilainya yang tercermin dalam tradisi keilmuan dan moralitasnya yang secara epistemik-etik diakui turut menentukan cara pandang dunia pesantren dalam menafsirkan realitas yang dihadapi dan dalam memberikan respon terhadapnya. Hanya saja, ke-ajeg-an dan kontinuitas yang ada pada pesantren tersebut, dalam beberapa sisi, justru diidentifikasi sebagai penyebab terjadinya kesenjangan antara pesantren dengan modernisasi dalam era globalisasi yang telah berlangsung di dunia "luar". Dalam hal ini Cak Nur, dalam analisisnya menyatakan bahwa kesenjangan pesantren dengan modernisasi paling tidak dipicu oleh enam hal yang pada umumnya masih menandai kondisi objektif pesantren, yaitu: ${ }^{8}$

1. Lingkungan. Tata lingkungan pesantren pada umumnya merupakan hasil partumbuhan dan pembangunan yang tidak terencana, sporadis, dan tidak memadai baik dari sisi kuantitas maupun kualitasnya.

2. Penghuni/santri. Adanya diskrepansi yang ditunjukkan para santri jika dibandingkan dengan komunitas luar baik menyangkut pakaian, kesehatan, maupun tingkah laku.

3. Kurikulum. Dalam dunia pesantren, pengajaran pengetahuan umum yang masih setengah-setengah, dominannya ilmu-ilmu keagamaan, sistem pengajaran yang kurang efisien, dan intelektualisme-verbalisme yang eksesif karena berorientasi pada penalaran produktif, bahkan cenderung menimbulkan dogmatisme dan prinsipalisme.

4. Kepemimpinan. Terdapat tolok ukur tertentu dalam kepemimpinan pesantren, yaitu kharisma, personal, religio-feodalisme, dan kurang mementingkan kecakapan teknis.

5. Alumni. Para alumni pesantren pada umumnya hanya cocok untuk jenis masyarakat "tradisional" dan kecenderungan mereka bersikap reaktif-agresif terhadap dunia luar, sehingga tidak akan sanggup bersaing dalam kehidupan modern.

6. Kesederhanaan. Walaupun kesederhanaan memang diakui melekat dengan pesantren, hal ini masih belum mendapatkan penekanan khusus dalam kurikulumnya dan belum mendapatkan pengarahan dalam penjiwaannya. 


\section{KOMERSIALISASI PENDIDIKAN}

Dalam dunia pendidikan termasuk di pesantren, pengaruh gelombang globalisasi yang ditandai dengan menguatnya paham pasar bebas juga begitu terasa. Pada era ini tradisi umat manusia untuk mempertahankan eksistensi mereka melalui pendidikan termasuk di dalamnya pendidikan pesantren mendapat tantangan serius, karena pendidikan ternyata bagi sebagian manusia dapat digunakan untuk mengakumulasi kapital dan mengeruk keuntungan sebagaimana disebutkan di atas. Bagaimana mungkin tradisi manusia tentang visi pendidikan sebagai strategi untuk eksistensi manusia yang telah direproduksi selama berabad-abad ini, diganti oleh suatu visi yang meletakkan pendidikan sebagai komoditi, ${ }^{9}$ yang pada gilirannya menjadikan pendidikan sebagai komoditas perekonomian. Pada kondisi ini pendidikan yang laik akan menjadi barang mahal, yang tidak semua orang mampu menjangkaunya.

Pandangan seperti ini secara langsung maupun tidak langsung merambah ke dunia pesantren. Dalam hal ini, perlu dicermati apakah pesantren memiliki kecenderungan menjadikan pendidikan sebagai komoditi. Secara historis, pesantren tumbuh dan berkembang di tengah masyarakat dan berbaur dengan masyarakat itu sendiri. Pesantren hidup dalam tradisi kesederhanaan, karena itu biaya pendidikan di pesantren relatif terjangkau oleh lapisan bawah sekalipun. Mahmud Arif menyebutkan beberapa kelebihan yang dimiliki pesantren di antaranya yaitu pertama, sistem pemondokan yang memungkinkan pendidik (kyai) melakukan tuntutan dan pengawasan secara langsung kepada santri. Kedua, keakraban (hubungan personal) antara santri dengan kyai dan antara santri dengan santri yang sangat kondusif bagi pemerolehan pengetahuan yang hidup. Ketiga, kemampuan pesantren mencetak lulusan yang memiliki kemandirian. Keempat, kesederhanaan pola hidup. Kelima, biaya pendidikan murah. ${ }^{10}$

\section{TANTANGAN KE DEPAN}

Sejak dahulu, pendidikan merupakan wahana terpenting bagi masyarakat, bahkan pesantren yang keberadannya di tengah-tengah masyarakat justru sering menjadi sentral kegiatan masyarakat baik sebagai wahana transformasi kebudayaan, sosialisasi dengan masyarakat sekitarnya, maupun sebagai wahana transformasi ilmu pengetahuan itu sendiri. Oleh karena itu bagi masyarakat, pendidikan merupakan elemen penting yang keberadaannya mengindikasikan keberadaan masyarakat itu sendiri.

Sejak zaman dahulu atau sekitar tahun 900-an Sebelum Masehi ketika pendidikan mulai dilembagakan di kota Sparta, pendidikan tidak pernah diarahkan untuk dirinya sendiri, akan tetapi pendidikan selalu dijadikan sebagai alat, terutama alat bagi manusia untuk menjaga eksistensinya.

Dalam konteks ini, pendidikan dapat menjadi alat menyalurkan ilmu pengetahuan, alat pembentukan watak, alat pelatihan keterampilan, alat penanaman ideologi tertentu, alat untuk meningkatkan pekerjaan, alat investasi, alat meningkatkan 
kesadaran untuk hidup bersama, alat untuk menciptakan keadilan sosial, alat untuk melanggengakan kekuasaan, alat untuk mendominasi kelompok tertentu dan lain sebagainya.

Sebagai alat, pendidikan diabdikan pada suatu atau beberapa tujuan yang hendak dicapai yang di dalamnya terkandung visi dan misi. Di sinilah terjadi perebutan pengaruh dari berbagai kekuatan lengkap dengan ideologinya masing-masing, yang tidak jarang mengorbankan proses dan tujuan sosial pendidikan itu sendiri. Pada kondisi ini kekuatan politik dan ekonomi memegang peranan penting. Politik dengan kekuatan kekuasaannya akan terus memaksakan pendidikan sebagai ajang perebutan pengaruh dan untuk mendominasi kelompok-kelompok tertentu, begitu pun dengan ekonomi, dengan kekuatan modalnya, pendidikan dijadikan ajang bisnis untuk mengeruk keuntungan sebanyak-banyaknya, sehingga terjadilah apa yang disebut komersialisasi pendidikan.

Pada kondisi ini pendidikan diletakkan sebagai komoditi yang pada akhirnya akan menjadi barang mahal, yang hanya dapat dijangkau oleh kelompok-kelompok tertentu saja, sedangkan masyarakat secara lebih besar tidak mampu menikmati kemajuan pendidikan karena keterbatasan ekonomi mereka. Ini yang patut menjadi renungan bersama, di mana saat ini terdapat kecenderungan pendidikan menjadi "barang mahal" yang hanya dapat diakses oleh kelompok-kelompok kaya "the have". Inilah yang harus dijawab oleh dunia pesantren agar mampu memberikan pelayanan pendidikan kepada masyarakat dari berbagai kalangan.

Dengan komoditisasi tersebut, akibatnya terjadi ketidakmerataan pendidikan di kalangan masyarakat, pendek kata terdapat ketimpangan pelayanan pendidikan. Pendidikan hanya mampu dijangkau oleh suatu kelompok yang secara ekonomi diuntungkan (mapan) oleh struktur dan sistem sosial yang ada. Sementara bagi mereka yang datang dari kelas yang dieksploitasi secara ekonomi tidak akan mampu atau katakanlah sulit menjangkau pendidikan, lebih khusus lagi pendidikan yang bermutu. Hal ini berarti, bagi mereka yang memiliki uang dan mampu membayarnya, maka ia akan memperoleh pelayanan dan mutu pendidikan yang maksimal, sementara yang tidak mampu, maka ia akan menikmati pendidikan seadanya, bahkan tidak jarang mereka tidak mampu mengakses pendidikan sama sekali. Pendidikan yang telah sekian lama menjadi usaha kolektif manusia untuk mempertahankan eksistensi dan budayanya, saat ini telah mengalami pergeseran orientasi, visi, misi dan ideologi yang berakibat pada ancaman bagi eksistensi manusia itu sendiri. Oleh karena itu, munculnya tayangan-tayangan "pendidikan gratis" harus betul-betul diwujudkan, sehingga mimpi-mimpi masyarakat untuk mendapatkan pendidikan bermutu tidak hanya terpelihara, melainkan lebih dari itu, yakni dapat terwujud dan dapat dirasakan secara langsung oleh masyarakat.

Pada kasus ini hakekat pendidikan yakni sebagai suatu strategi kebudayaan manusia untuk mempertahankan eksistensi dan budayanya telah telah dirontokkan oleh sistem ekonomi yang lebih menekankan pada aspek permodalan yang telah melahirkan kelas-kelas di masyarakat. Semua sistem dan struktur ekonomi kapitalis- 
tik telah membuat praktek pendidikan justru melanggengkan kelas sosial dan ketidakadilan sosial. Untuk itu apa yang dilakukan pesantren dengan kemampuannya mengakomodasi dari berbagai kelompok masyarakat pada dasarnya merupakan upaya untuk mencegah agar pendidikan tidak sampai berakibat menjadikan manusia terdidik menjadi eklusivistik, elitis karena kedudukannya sebagai kelas terpelajar.

Dalam kaitannya dengan globalisasi yang menghadirkan sejumlah peluang positif untuk hidup lebih mudah, nyaman, murah, indah dan maju; juga dapat menghadirkan peluang negatif sekaligus, yaitu menimbulkan keresahan, penderitaan dan penyesatan. Globalisai bekerja selama 24 jam dengan menawarkan banyak pilihan dan kebebasan yang bersifat pribadi. Pendek kata dewasa ini telah terjadi banjir pilihan dan banjir peluang. Terserah kemampuan seseorang untuk memilihnya. U. Thant, mantan Sekjen PBB pada tahun 1970-an, mengatakan bahwa saat ini sumber daya tidak lagi membatasi keputusan, akan tetapi keputusanlah yang menciptakan sumber daya. ${ }^{11}$

Dalam perspektif pendidikan, mampukah kita menciptakan dan mengembangkan sistem pendidikan yang menghasilkan lulusan yang mampu memilih tanpa kehilangan peluang dan jati dirinya. Karena kecenderungan globalisasi tersebut merupakan suatu gejala yang tidak dapat dihindari, oleh karena itu banyak gagasan dalam menghadapi globalisasi ini yang menekankan perlunya berpikir dan berwawasan global namun harus tetap menyesuaikan keputusan dan tindakan dengan kenyataan nyata di depannya. Muchtar Buchori sebagaimana yang dikutip Umar Tirtaraharja dan S. L. La Sulo, berpendapat "think globally but act locally". Untuk latar Indonesia yang menganut semboyan Bhineka Tunggal Ika, hal itu tidak hanya mempertimbangkan aspek nasional tetapi juga aspek lokal di daerah yang bersangkutan.12

Dengan pesatnya perkembangan teknologi komunikasi dan informasi sebagai akibat dari gelombang globalisasi, maka sebenarnya hal ini merupakan peluang bagi pendidikan di pesantren untuk mengembangkan dirinya secara lebih baik dan merata. Paling tidak, dengan persediaan dan pengembangan teknologi pembelajaran yang tiada henti akan lebih memacu kualitas pembelajaran yang berbasiskan teknologi agar semakin ditingkatkan.

Dalam hal pemerataan pendidikan, dengan pesatnya perkembangan teknologi komunikasi dan informasi paling tidak mampu menyelenggarakan pendidikan di daerah-daerah terpencil, misalnya dengan model pendidikan jarak jauh. Hal ini merupakan peluang untuk lebih meningkatkan kualitas dan pemerataan pendidikan di Indonesia. Sehingga diharapkan terjadi peningkatan baik dari segi kualitas maupun kuantitas peserta didik yang mengikuti pendidikan.

Di sinilah kemampuan dan ketajaman strategi manusia-manusia pendidikan Indonesia diuji. Oleh karena itu diperlukan suatu pengembangan strategi baru dalam menghadapi gelombang globaliasasi ini. Dalam menyikapi gelombang globalisasi yang semakin pesat, UNESCO (United Nations Educational, Scientific and Cultural Organization) menyikapinya dengan mengukuhkan kembali beberapa rekomendasi pada Oktober 1994 di Jenewa, yang tertuang dalam dokumen UNESCO, Integrated Framework of Action on Education for Peace, Human Right and Democracy, yaitu: ${ }^{13}$ 
1. Pendidikan hendaknya mengembangkan kemampuan untuk mengakui dan menerima nilai-nilai yang ada di dalam kebhinekaan pribadi, jenis kelamin, masyarakat dan budaya serta mengembangkan kemampuan untuk berkomuni-kasi, berbagi dan bekerjasama dengan yang lain.

2. Pendidikan hendaknya meneguhkan jati diri dan mendorong konvergensi gagasan dan penyelesaian-penyelesaian yang memperkokoh perdamaian, persaudaraan dan solidaritas antara pribadi-pribadi dan masyarakat.

3. Pendidikan hendaknya mengembangkan kemampuan penyelesaian konflik secara damai tanpa kekerasan. Oleh karena itu maka pendidikan hendaknya juga meningkatkan pengembangan kedamaian dalam diri dan pikiran peserta didik, sehingga dengan demikian mereka mampu membangun secara lebih kokoh kualitas toleransi, kesabaran, kemauan untuk berbagi dan memelihara.

4. Pendidikan hendaknya menanamkan perasaan solidaritas dan kesamaan pada peringkat nasional dan internasional, dalam perspektif pembangunan yang seimbang dan lestari.

Keempat rekomendasi UNESCO tersebut merupakan strategi pendidikan dalam menghadapi pesatnya gelombang globaliasasi. Akan tetapi yang tidak kalah pentingnya, yakni strategi penguatan internal institusi lembaga pendidikan termasuk pesantren yang meliputi:

1. Penguatan institusi dengan kebijakan-kebijakan yang mendukung. Di sini reformasi pendidikan perlu mengembangkan sejumlah kebijakan makro maupun mikro dalam rencana jangka panjang, jangka menengah dan jangka pendek. ${ }^{14}$

2. Penataan manajemen mulai dari perencanaan hingga evaluasi, yang tidak hanya berorientasi pada mutu hasil melainkan juga pada mutu proses pelaksanaan. Sebagaimana diketahui aspek manajemen ini sering menjadi kelemahan pesantren.

3. Pengembangan dan peningkatan kualitas Sumber Daya Manusia, tanpa SDM yang unggul maka akan sulit bahkan mustahil dapat meningkatkan pendidikan yang mampu survive dan bersaing dengan perkembangan global.

4. Kemampuan beradaptasi dengan pergaulan global atau internasional, ini tentunya membutuhkan pengetahuan, wawasan global dan kemampuan berkomunikasi serta kemampuan berbahasa.

Pada akhirnya strategi ini akan sangat tergantung pada kuatnya kemauan dan kemampuan manusia-manusia pendidikan Indonesia untuk memanfaatkan peluangpeluang yang tersedia di era globaliasasi ini. Dalam konteks ini, pesantren telah terbukti mampu menampilkan diri sebagai institusi yang tetap eksis dalam menghadapi segala bentuk dinamika perubahan sosial dengan dua karakter utama budaya pendidikannya yaitu: ${ }^{15}$

1. Karakter budaya yang memungkinkan santri belajar secara tuntas, tidak hanya terbatas pada transfer ilmu-ilmu pengetahuan, akan tetapi juga aspek pembentukan kepribadian secara menyeluruh

2. Kuatnya partisipasi masyarakat. Oleh karena itu sangatlah wajar sekiranya pesantren kemudian banyak dirujuk, paling tidak pada awal masa pasca kemerdekaan, untuk dijadikan sebagai acuan alternatif dalam menghadapi kebuntuan upaya 
merumuskan sistem perguruan nasional yang tidak tercerabut dari akar historis ke-Indonesiaan dan juga tidak berkurang efisiensi dan efektifitasnya.

\section{CATATAN AKHIR:}

1. Haidar Putra Daulay, Sejarah Pertumbuhan dan Pembaharuan Pendidikan Islam di Indonesia, Jakarta: Prenada Media, 2007, h. 62-63.

2. Abdurrahman Mas'ud, Dari Haramain ke Nusantara; Jejak Intelektual Arsitek Pesantren, Jakarta: Prenada Media Group, 2006, h. 1.

3. Sudjoko Prasodo, et. al, Profil Pesantren, Jakarta: LP3ES, 1981, h. 6.

4. Zamakhsyari Dhofier, Tradisi Pesantren Studi Tentang Pandangan Hidup Kyai, Jakarta: LP3ES, h. 44.

5. Mahmud Arif, Pendidikan Islam Transformatif, Yogyakarta: LKiS, 2008, h. 196.

6. Enung K. Rukiati, dan Fenti Hikmawati, Sejarah Pendidikan Islam di Indonesia, Bandung: Pustaka Setia, 2006, h. 104.

7. H.A.R. Tilaar, Manajemen Pendidikan Nasional: Kajian Pendidikan Masa Depan, Bandung: Remaja Rosdakarya, 2001, h. 4.

8. Mahmud Arif, Pendidikan Islam Transformatif, Yogyakarta: LKiS, 2008, h. 169-170.

9. Mansour Faqih dalam Pengantar Francis Wahono, Kapitalisme Pendidikan Antara Kompetisi dan Keadilan, Yogyakarta: Insist Press, Cindelaras dan Pustaka Pelajar, 2001, h. xi.

10. Muhammad Arif, Pendidikan Islam Transformatif, Yogyakarta: LKiS, 2008, h. 168

11. Mastuhu, Menata Ulang Pemikiran Sistem Pendidikan Nasional dalam Abad 21, Yogyakarta: Safiria Insania Press, 2003, h. 10.

12. Umar Tirtaraharja dan S. L. La Sulo, Pengantar Pendidikan, Jakarta: Rineka Cipta, 2005, h. 134-135.

13. M. Dawam Rahardjo, (ed), Keluar Dari Kemelut Pendidikan Nasional: Menjawab Tantangan Kualitas Sumber Daya Manusia Abad 21, Jakarta: Intermasa, 1997, h. 54.

14. Azyumardi Azra, Paradigma Baru Pendidikan Nasional: Rekonstruksi dan Demokratisasi, Jakarta: Kompas, 2002, h. xvii.

15. Mahmud Arif, Pendidikan Islam Transformatif, Yogyakarta: LKiS, 2008, h. 168.

\section{DAFTAR PUSTAKA:}

Arif, Muhammad., Pendidikan Islam Transformatif, Yogyakarta: LKiS, 2008

Azra, Azyumardi, Paradigma Baru Pendidikan Nasional: Rekonstruksi dan Demokratisasi, Jakarta: Kompas, 2002.

Daulay, Haidar Putra., Sejarah Pertumbuhan dan Pembaharuan Pendidikan Islam di Indonesia, Jakarta: Prenada Media, 2007.

Dhofier, Zamakhsyari, Tradisi Pesantren Studi Tentang Pandangan Hidup Kyai, Jakarta : LP3ES.

Mas'ud, Abdurrahman., Dari Haramain ke Nusantara; Jejak Intelektual Arsitek Pesantren, Jakarta: Prenada Media Group, 2006.

Mastuhu, Menata Ulang Pemikiran Sistem Pendidikan Nasional dalam Abad 21, Yogyakarta: Safiria Insania Press, 2003.

Mastuhu, The New Mind Set of National Education in the 21st Century, Yogyakarta: Safiria Insania Press bekerjasama dengan MSI Universitas Islam Indonesia, 2003.

Prasodo, Sudjoko, et. al, Profil Pesantren, Jakarta: LP3ES, 1981.

Rahardjo, M. Dawam (ed), Keluar Dari Kemelut Pendidikan Nasional: Menjawab Tantangan Kualitas Sumber Daya Manusia Abad 21, Jakarta: Intermasa, 1997. 
Rukiati, Enung K. dan Fenti Hikmawati, Sejarah Pendidikan Islam di Indonesia, Bandung: Pustaka Setia, 2006.

Tilaar, H.A.R., Manajemen Pendidikan Nasional: Kajian Pendidikan Masa Depan, Bandung: Remaja Rosdakarya, 2001.

Tirtaraharja, Umar dan S. L. La Sulo, Pengantar Pendidikan, Jakarta: Rineka Cipta, 2005.

Wahono, Francis, Kapitalisme Pendidikan Antara Kompetisi dan Keadilan, Yogyakarta: Insist Press, Cindelaras dan Pustaka Pelajar, 2001. 